\title{
ARTEFATOS EM MIRITI E A REPRESENTAÇÃO DE CORPOS MASCULINOS E FEMININOS
}

\author{
Joyce Ribeiro $^{1}$ \\ Lidia Sarges ${ }^{2}$ \\ Madna Pinheiro ${ }^{3}$
}

\section{Introdução}

Neste artigo faremos uma reflexão inicial sobre a representação do corpo masculino e do feminino nos artefatos em miriti, mais especificamente na peça casal de namorados e/ou casal de dançarinos ${ }^{4}$. O artigo resulta de pesquisa cultural desenvolvida durante os anos de 20132015, cujo um dos objetivos foi a análise das relações de gênero em dois ateliês de produção dos artefatos em miriti, em Abaetetuba, cidade ribeirinha do estado do Pará. A interpretação tem lugar no campo dos Estudos Culturais, uma tradição teórico-metodológica e política, cujas características mais expressivas são a versatilidade teórica, a alquimia, e a interdisciplinaridade, tudo para dar conta de seus objetos de pesquisa, quais sejam, os processos subjetivos inerentes à relação cultura-sociedade (JOHNSON, 2000). Neste campo, a cultura constitui-se em um conjunto de significados produzidos em uma arena contestada em meio ao poder e à diferença, o que lhe imprime um caráter aberto, plural, fluido, que é aceito, resistido e negociado.

$\mathrm{O}$ trabalho de campo se estendeu por dez meses em dois ateliês, um ligado à $\mathrm{Asamab}^{5} \mathrm{e}$ outro à Miritong ${ }^{6}$, tendo se materializado dentro dos flexíveis contornos da etnografia pósmoderna. Esta é constituída a partir da crítica aos limites da etnografia realista ${ }^{7}$ - cujos pressupostos relativos à objetividade, neutralidade e relação sujeito-objeto são definidos nos marcos da ciência moderna - que culmina no esforço de descrever a cultura. A etnografia pósmoderna é influenciada pela virada linguística ${ }^{8}$ e pela desconstrução ${ }^{9}$, e se caracteriza, grosso modo, pela contingência, pela objetividade provisória, pela influência das relações de poder na relação sujeito-objeto, o que inevitavelmente fará com que a pesquisa seja marcada por intenções, interesses, conflitos e negociações. A despeito das diferenças teóricas, a norma para

1 Professora de Didática da FAECS/Campus Universitário de Abaetetuba/UFPA; Professora do PPEB/ICED/UFPA na linha de pesquisa Currículo da Escola Básica; líder do Gepege - Grupo de Estudos e Pesquisa Gênero e Educação. E-mail: joyce@ufpa.br.

${ }^{2}$ Aluna do curso de Pedagogia da Faecs/Campus Universitário de Abaetetuba/UFPA; bolsista Pibic interior/2015-16; integrante do Gepege - Grupo de Estudos e Pesquisa Gênero e Educação.

${ }^{3}$ Aluna do curso de Pedagogia da Faecs/Campus Universitário de, Abaetetuba/UFPA; bolsista Pibex 2015-16; integrante do Gepege - Grupo de Estudos e Pesquisa Gênero e Educação.

${ }^{4}$ Este artigo resulta da pesquisa intitulada $\mathrm{O}$ brinquedo de miriti do município de Abaetetuba: a tradução da tradição de um artefato pedagógico-cultural por meio das intersecções de gênero e sexualidade, Prodoutor 2013-15.

${ }^{5}$ Associação de artesãos e artesanato de miriti.

${ }^{6}$ Associação Arte em Miriti.

${ }^{7} \mathrm{O}$ termo etnografia realista é usado por Marcus e Cushman (2008) e outros; o termo realismo remete a um modo de escrever do século XIX, pautado na abundância de detalhes objetivando representar fielmente a realidade.

${ }^{8}$ A virada linguística é "[...] o momento no qual o discurso e a linguagem passaram a ser considerados como centrais na teorização social”' (SILVA, 2000, p. 111).

${ }^{9}$ A desconstrução é um modo de crítica que questiona processos que ocultem a construção social de um objeto, documento, evento, sujeito ou representação; para descontruir é imperativo toma-los como texto e proceder a leitura destacando suas ambiguidades (SILVA, 2000). 
o trabalho de campo segue ancorada na observação cotidiana e nas conversações com os interlocutores e interlocutoras.

Organizamos o artigo de modo a iniciar esclarecendo sobre a tradição bicentenária dos artefatos em miriti para, em seguida, descrever um de seus elementos, qual seja, o processo que estamos denominando de produção generificada, anunciando a cultura de gênero que circula no espaço; encerramos buscando compreender um de seus efeitos: a modelagem e a montagem da peça casal de namorados-casal de dançarinos e a representação do corpo masculino e feminino.

\section{Os elementos da tradição dos artefatos em miriti}

A tradição dos artefatos em miriti é bicentenária em Abaetetuba, cidade ribeirinha localizada relativamente próxima à Belém, a capital do estado do Pará. Além de ser a peçachave desta tradição, estes artefatos são considerados patrimônio cultural imaterial do estado e elemento estruturante da maior festa religiosa do Pará, o Círio de Nazaré ${ }^{10}$.

Esta é uma tradição de origem popular, preservada pela memória oral; os conhecimentos culturais que circulam sobre, informam que as primeiras iniciativas para modelar o miriti foi de crianças ribeirinhas ${ }^{11}$ que, sem acesso aos brinquedos industrializados, usavam o miriti para produzir pequenos barcos e canoas que flutuavam com facilidade nos rios e igarapés, proporcionando os prazeres do lúdico. Com o tempo, os brinquedos de miriti passaram a ser comercializados em feiras e mercados.

A tradição dos artefatos em miriti é uma entre as muitas tradições que ainda sobrevivem atualmente e que foram inventadas nos séculos XVIII e XIX, quando a Europa sofreu os efeitos dos eventos políticos e culturais que transformaram a feição das sociedades ocidentais (HOBSBAWN, 1984). Naquele contexto, as tradições foram inventadas com a finalidade de disseminar os valores republicanos, porém, no Brasil, o objetivo era de, por meio do folclore, construir uma cultura nacional que incluísse o país no conjunto das nações cultas. Mais adiante, no período do modernismo brasileiro, o artesanato, o folclore e a cultura popular foram tratados como representantes da essência nacional e, por isso, muito usados para preservar tradições e costumes considerados ameaçados de extinção.

A tradição é um discurso capaz de produzir sentimentos e condutas politicamente sancionadas, e funciona semelhante a religião, pois mesmo laica trata-se de uma forma de fé (HOBSBAWN, 1984), na medida em que é amplamente aceita. Os artefatos em miriti são duplamente centrais para Abaetetuba: centralidade econômica, pois aquecem a economia garantindo renda adicional à centenas de famílias; e centralidade cultural, pois além de ser elemento de uma bicentenária tradição, é patrimônio cultural imaterial, o que proporciona visibilidade, prestígio e diferenciação à cultura local, tendo efeitos na constituição de identidades pelo orgulho de pertencer.

A matéria-prima usada na produção de tais artefatos é o pecíolo, braço ou "bucha" retirada da palmeira do miriti, espécie abundante na região das Ilhas de Abaetetuba (SILVEIRA, 2012). A "bucha" do miriti é leve e quebradiça - levando-o a ser chamado de isopor da Amazônia - e é esta maleabilidade que possibilita a grande riqueza de detalhes, assim como os ferimentos recorrentes nas mãos dos artesãos. As peças ainda guardam certo aspecto de rusticidade, mas

\footnotetext{
${ }^{10}$ Pela certidão do IPHAN/2004, o brinquedo de miriti é elemento estruturante do Círio de Nazaré; a Lei estadual n. 7433/2010, concede o título de patrimônio cultural imaterial do Estado do Pará.

${ }^{11}$ Ribeirinhos são parte da população tradicional; residem às margens dos inúmeros rios que cortam a Amazônia, sobrevivendo da pesca, da agricultura e do extrativismo.
} 
atravessaram o tempo e chegaram aos dias atuais por meio da iniciativa das associações existentes e do dedicado trabalho de artesãos e artesãs.

Em geral, os artefatos em miriti são considerados artesanato, mas há o desejo de alguns artesãos - especialmente os da Miritong - de que este seja qualificado como arte, e os artesãos, artistas, e por isso fazem questão de ressaltar que se dedicam à arte em miriti. Para não nos estendermos em demasia neste ponto, para o momento é o bastante argumentar que "[...] nas cerâmicas, nos tecidos e retábulos populares é possível encontrar tanta criatividade formal, geração de significados originais e ocasional autonomia com respeito às funções práticas quanto na arte culta" (CANCLINI, 1989, p. 245). Então, é possível concluir que os processos inerentes tanto à arte quanto ao artesanato são os mesmos, inexistindo inutilidade, gratuidade ou desinteresse na arte, e/ou rusticidade e mitologia no artesanato, na medida em que ambos são atravessados por redes de dependência que envolvem o mercado, a indústria cultural, e referentes de ambas as manifestações culturais, o que acaba por hibridizar tais artefatos.

As pessoas que produzem os artefatos em miriti são consideradas especiais, pois são consideradas como as responsáveis pela manutenção desta tradição, "para que ela nunca morra" como afirmou José Roberto, um artesão-chefe ligado a Asamab. Ser artesão-artesã modela um modo de vida diferente e que parecem gostar, pois por meio deste artesanato, conseguem relacionar-se com a sociedade realizando oficinas e cursos, participando de eventos (exposições e feiras) regionais, nacionais, e internacionais. Além do enaltecimento da tradição pelos motivos já indicados anteriormente, há a vontade de ser referência cultural, pois este artefato é único, já que só existe em Abaetetuba, o que garante certo status.

Porém, a despeito disso, para artesãos e artesãs a situação não é tão idílica como àquela divulgada e incansavelmente repetida nos blogs e sites que tratam da cultura abaetetubense. A despeito de ser considerados os grandes responsáveis pela manutenção da tradição e do patrimônio cultural, a beleza das peças está longe de dar sentido às suas vidas, dada a precariedade de suas condições de existência e de trabalho. Senão vejamos: os artesãos mantém a produção dos brinquedos em ateliês-residências, dividem a produção artesanal com outras atividades fontes de renda devido aos baixos salários, tem pouco ou quase nenhum incentivo financeiro público e/ou privado, não dispõem de mão-de-obra especializada quando de uma grande encomenda, usam peças rudimentares e rústicas para modelar, e não dispõem de equipamentos de segurança o que os expõe cotidianamente à constantes ferimentos nas mãos e a problemas dermatológicos e respiratórios devido a poeira constante, bem como ao forte odor da massa e do selador (alguns produtos liberam gases tóxicos no ar ou deixam resíduos na pele); além disso, é importante destacar que a atividade repetitiva ocasiona problemas ósseos e musculares, como o observado em uma artesã, que apresentava um dos braços visivelmente maior que o outro. Portanto, o cenário é desolador (RIBEIRO; SARGES; PINHEIRO, 2015). É assim porque há paradoxos na cultura, expressos em movimentos de inclusão e exclusão. No primeiro, os artesãos são essas figuras quase míticas que produzem os famosos artefatos, mantendo viva a tradição e o patrimônio cultural; no segundo, suas condições de existência visibilizam uma exclusão concreta, traduzida em dificuldades de acesso aos bens simbólicos e materiais da sociedade, afinal, são considerados pela autoridade cultural como caboclos, indolentes, incultos e rústicos.

Durante a pesquisa, identificamos alguns elementos desta tradição, isto é, aspectos que a estruturam como: os temas, a estética dos brinquedos (dimensão e pintura), e a produção generificada.

Em relação aos temas, há os tradicionais e os inovadores. Segundo José Roberto, os mais procurados são os tradicionais, aqueles que remetem ao modo de vida ribeirinho, à cultura amazônica, com peças que representam cenas pitorescas da vida cotidiana ribeirinha, representadas por palafitas, canoas, frutas apreciadas, animais, a religiosidade, a intimidade, $\mathrm{o}$ 
lazer e o trabalho (extrativismo e agricultura familiar). Assim, os artefatos em miriti acabam por se constituir em artefatos-síntese do regionalismo, da identidade Amazônida, pois passa ou quer passar a impressão de ser o reflexo fiel da realidade.

Os temas inovadores são os influenciados pela cultura midiática e tecnológica, como personagens de desenhos animados, super-heróis, e artefatos como rádios, computadores, celulares, tablets, motocicletas, helicópteros, câmeras fotográficas, entre muitos outros. As peças são apresentadas em miniaturas entalhadas com abundância de detalhes e colorido vibrante. Quanto à estética dos artefatos, este é um aspecto que desperta atenção e a despeito da beleza, ainda guarda certos traços de rusticidade. Os artefatos em miriti são apresentados em peças miniaturizadas, repletas de detalhes e colorido vibrante.

Esses elementos constituem hoje a tradição dos artefatos em miriti. Clifford (1994) argumenta que certos objetos antigos possuem sentido de profundidade e história passada, especialmente quando não são produzidos em massa o que leva certos grupos a preservá-los e valorizá-los, em razão de qualidades retrospectivas, inventivas e de autenticidade que agregam. Assim, o brinquedo de miriti atravessou o tempo e chegou aos dias atuais por meio da iniciativa das duas associações existentes e do dedicado trabalho de artesãos e artesãs. Entre estes últimos, o discurso da tradição é recorrente, pois José Roberto considera que esta "resgata a memória e os valores que estão desaparecendo de Abaetetuba". Por conta disso, a tradição é enaltecida, havendo um permanente esforço para garantir sua continuidade.

\subsection{A produção generificada nos ateliês}

A produção dos artefatos em miriti se dá por meio do trabalho artesanal, realizado em ateliês familiares. A sede dos dois ateliês etnografados é a própria casa da família; assim, em cada ateliê trabalham o pai, a mãe, os filhos, as filhas, alguns agregados e também artesãos contratados. Assim, há homens, mulheres, jovens e adultos interagindo nestes espaços.

Observamos que a produção é organizada pelo que denominamos de produção generificada, um processo caracterizado pela divisão de tarefas por gênero, sustentado na crença da existência de trabalho bruto e de trabalho leve. Em geral, o trabalho bruto é o masculino e envolve o cortarmodelar, lixar e selar; o trabalho leve é o destinados às mulheres, e consiste de tarefas como a pintura e o acabamento (contorno) com caneta preta apropriada.

Durante o trabalho de campo, nos chamou atenção o fato de em ambos os ateliês o corte ser reponsabilidade do homem, do artesão-chefe, que em geral é dono de ateliê e chefe da família de artesãos. Os homens são responsáveis pelo corte em dois momentos: corte das "buchas" do miritizeiro e o corte-modelagem. Em geral, qualquer homem pode cortar as folhas da palmeira do miritizeiro para dela extrair a "bucha", a matéria prima dos artefatos. Porém, o corte-modelagem é considerado um dom, uma tarefa quase sagrada, ancorada, segundo Canclini (1989), na fé de que a inspiração emana dos deuses.

Este dom compete só aos homens destemidos e habilidosos, pois os artesãos-chefe que foram interlocutores nesta pesquisa, este não é um trabalho simples e fácil, pois requer muita destreza e técnica. $\mathrm{O}$ artesão-chefe, para proceder ao corte-modelagem manuseia uma faca com fio cortante, considerada excessivamente perigosa, pois cotidianamente até o artesão mais hábil e cuidadoso sofre com ferimentos nas mãos. A permanente ameaça de ferimentos em mãos pouco habilidosas mantém o corte-modelagem como tarefa masculina. O corte-modelagem expressa a marca particular de cada artesão-chefe, e um observador atento a identifica com certa facilidade.

Há vários discursos que justificam a generificação da produção: o suposto perigo e a exigência de habilidade produz e reproduz a masculinização do corte-modelagem; e ideia de 
que a Mulher é naturalmente frágil, delicada, paciente, cuidadosa, e preocupadas com a aparência, mantém a feminização da pintura.

Observamos que a produção generificada está naturalizada, pois a artesã Marinilda chegou a ressaltar que jamais percebeu a divisão de tarefas, e que jamais percebeu este problema, pois "os homens sempre cortaram e as mulheres sempre pintaram". A naturalização da cultura de gênero no cotidiano só é possível devido a repetição histórica. A normatividade das experiências cotidianas para homens e mulheres já estava prevista na Grécia clássica, e esta definia um detalhado conjunto de normas que interditavam e estilizavam as condutas, por meio de um extenso e minucioso código normativo. Estas prescrições diferenciam e consideram o homem um sujeito viril, que domina a si mesmo, para depois dominar os outros; e a mulher, um ser frágil e naturalmente procriadora, logo, deve ficar sob o cuidado da família ou do marido (RIBEIRO, 2010). Estes imperativos sobre como deve ser um homem e uma mulher configuram a masculinidade e a feminilidade hegemônicas, o modo certo de ser homem e mulher, o padrão aceito universalmente.

Estes imperativos chegaram aos dias atuais e estão disseminados por toda a sociedade, e assim, circulam nos dois ateliês; porém, há pequenas singularidades em cada um deles: no da Asamab a produção generificada, é reforçada pela espacialização arquitetural, promovendo o separatismo de gênero, na medida que há salas para os homens e para as mulheres, o que impede a circulação e a comunicação entre eles e elas; no da Miritong, há certa ultrapassagem de fronteiras, expressa na contestação e subversão da norma imposta, materializada na troca de tarefas, na medida em que uma mulher lixa e um homem pinta.

Observamos a suspensão do cotidiano da produção generificada em ambos ateliês, momento em há o afrouxamento autorizado das normas de gênero, isto é, quando de uma grande encomenda, associada a prazos curtos. Neste momento, mulheres cortam-modelam e homens pintamcontornam, com a única intenção de garantir a entrega; quando a encomenda é entregue, o cotidiano volta à "normalidade". Em razão do espaço, não aprofundaremos esta análise, mas é possível dizer que as relações de poder, os interesses, as negociações, e a diferença, desenham um mapa de gênero no mínimo curioso nos dois ateliês ${ }^{12}$. Esta paisagem produz uma arte de viver e subjetiva artesãos e artesãs no momento de definir a estética das peças ${ }^{13}$, já que nestas há um conjunto de valores e ideias sobre corpo, gênero e sexualidade que irão circular na sociedade.

\section{A peça casal de namorados-casal de dançarinos e o corpo idealizado}

Vamos iniciar esta parte relatando um evento ocorrido no ateliê da Miritong, por considerarmos particularmente expressivo neste caso. Em certa ocasião, uma jovem artesã chamada Alcione (19 anos) montava a peça casal de namorados-dançarinos quando quase colou duas bonecas. Sua reação foi rápida, e mesmo assustada pelo seu engano, riu de si mesma e imediatamente tratou de buscar um boneco para formar o "par certo", mas destacando apressada que "não tem preconceito, mas é a peça que exige um homem e uma mulher".

\footnotetext{
12 Sobre as contestações e negociações nos ateliês em breve estará disponível: SARGES, Lidia; PINHEIRO, Delisa; RIBEIRO, Joyce. A tradição do brinquedo de miriti no currículo das escolas do município de Abaetetuba: iniciando o debate. Margens. ISSN 1806 0560, v. 6, n. 12, 2015. No prelo.

${ }^{13}$ Recentemente, durante trabalho de campo no ateliê do artesão-chefe Pirias, este nos informou que produz o casal de namorados homoafetivo e que tem muita saída; relevante também neste aspecto, é o relato da artesã Rosiane Peixoto, de que certos compradores/as desta peça, solicitam descolar o casal heteronormativo para compor um casal homoafetivo; Rosiane Peixoto informou também, que no ateliê de seu pai, o artesão-chefe conhecido como diabinho, as bonecas são voluptuosas, modeladas com seios e nádegas grandes e que, ao questioná-lo sobre porque as bonecas são "peitudas e bundudas", ele respondeu: "as bonecas são minhas e eu faço do jeito que eu quiser".
} 
A peça casal de namorados-casal de dançarinos consiste na representação de um casal heteronormativo. Percebemos uma pequena diferença que os faz ser considerados namorados ou dançarinos: a posição dos rostos, que no primeiro caso (imagem 1) simula um beijo na boca, e no segundo (imagem 2 e 3), os rostos estão apenas próximos como em uma dança.

Imagem 1

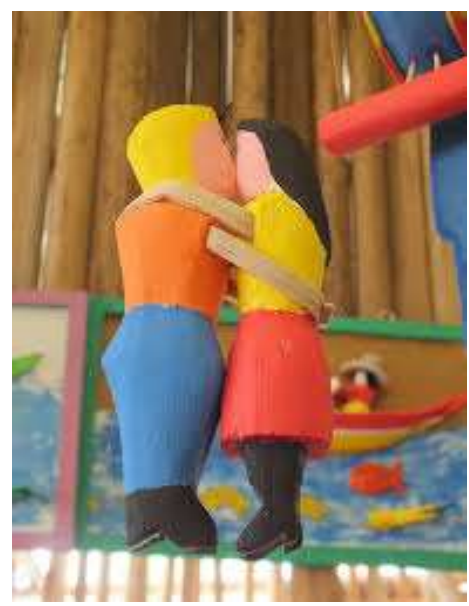

Imagem 2

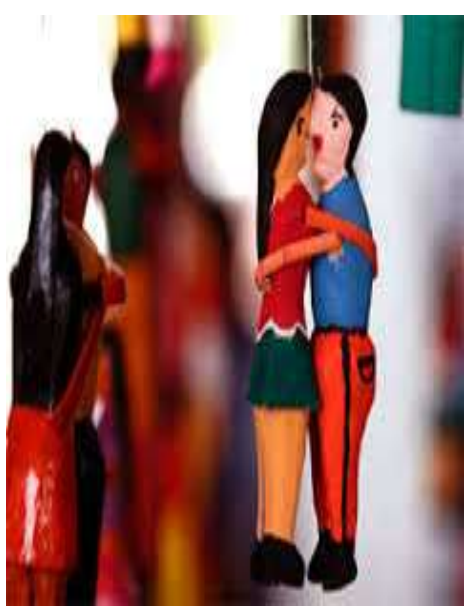

Imagem 3

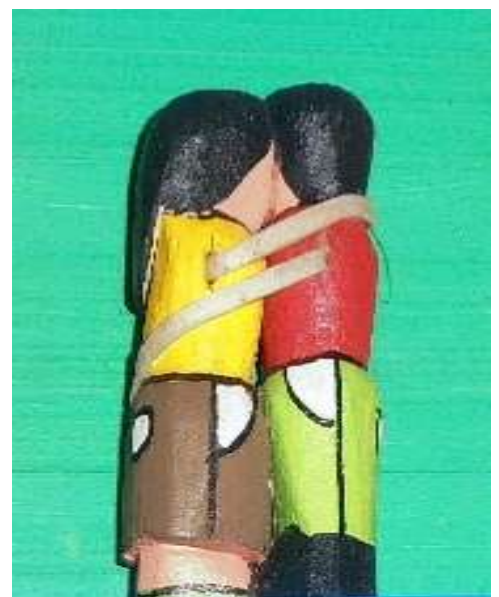

Fonte: Imagens 1 e 2 - <http://www.google.com>; Imagem 3 (Sarges, 2015 - diário de campo).

Nas três imagens é possível perceber as marcas de gênero na plástica dos corpos masculinos e femininos idealizadas, expressas no corte dos cabelos e nas roupas. Os bonecos que representam o homem têm cabelos curtos, e estão vestidos com calças compridas e camisa com mangas curtas; e as bonecas que representam a mulher, possuem cabelos longos e vestem saias. Os bonecos da peça são a imagem dos gêneros hegemônicos, em razão do corpo ser considerado veículo de significados sobre o que é adequado e aceitável para homens e mulheres, neste caso em relação ao vestuário, ao corte de cabelo e ao par romântico de modo a identificálos já na primeira mirada.

A sociedade controla o indivíduo por meio do corpo, na medida em que faz agir sobre este um conjunto de dispositivos com a finalidade de disciplinamento, para levar o sujeito a cuidar de si (FOUCAULT, 1987). Nos ateliês, além das normas disseminadas pela produção generificada, há a disseminação de princípios organizadores para o cuidado com o corpo, muito eficientes, e que integram o que Bordo (1997) chama de economia do corpo, cujo objetivo é a um só tempo a homogeneização-diferenciação de suas marcas. Homogeneização na medida em que todas as mulheres e todos os homens devem vestir-se, pentear-se, andar, gesticular, falar, olhar e sorrir conforme o script de seu gênero; diferenciação, na medida em que este script é distinto para mulheres e homens.

Deste modo, os cabelos identificam os gêneros, e funcionam como um sinal visual, pois sempre houve uma estética diferenciada para eles e elas ${ }^{14}$. Hoje, os homens mantem cabelos curtos, apesar da onda metrossexual que prevê penteados descolados, com uso de tintura e pomadas, sem deixar de sublinhar a moda dos cabelos completamente raspados dos desportistas famosos e astros do hip hop. Porém, os mais conservadores asseveram que cabelos compridos "não é cabelo de homem".

\footnotetext{
${ }^{14}$ Nos chamou atenção o boneco loiro, pois o homem mestiço (ribeirinho, caboclo, indígena) é o mais comum na região terreno de pesquisa, porém, adiaremos esta reflexão.
} 
Segundo Morris (2007), para as mulheres os cabelos significam glória e feminilidade, e seu poder de sedução ainda é motivo de tabus religiosos. "Nenhuma outra parte do corpo feminino passou por tantas e incríveis mudanças sociais" (MORRIS, 2007, 19). Hoje há muitos modelos de cortes e penteados e o mais comum em tempo de potente influência midiática, é a busca pelas "[...] longas madeixas flutuantes da pop star" (MORRIS, 2007, p. 21) da vez, sem esquecer ainda que cabelos longos simbolizam a juventude, e como a mídia tem focado no corpo feminino jovem, os cabelos precisam obrigatoriamente ser longos. Os cabelos longos têm o poder de seduzir pelo seu potencial erótico, mas também podem simbolizar liberdade de espírito, rebeldia e criatividade.

Os cabelos, tanto para eles quanto para elas, expressam a diferença, e com cortes diferenciados para os gêneros, almejam a identificação inequívoca. Os cortes e penteados são definidos não apenas para homens e mulheres, mas se considerarmos outros marcadores, como raça-etnia, geração, sexualidade, classe, religião, nação, profissão, teremos aí, uma extensa listagem de regras.

Entre os dispositivos que intervêm nos corpos estão as roupas. Considerando isso, o corpo não é ou está isolado, mas é constituído por tudo que está ao seu redor, produzindo imagens e sentidos. As roupas marcam o corpo masculino e o feminino também com a intenção de identificar inequivocamente o homem e a mulher, pois a roupa expressa a diferença, logo, há roupas para heterossexuais e homossexuais, para crianças, jovens e velhos (STALLYBRAS, 1999).

$\mathrm{Na}$ peça em análise, as saias são recorrentes, inclusive as minissaias o que imprime contemporaneidade ao artefato. As saias começaram a encurtar a partir de 1920, quando uma nova moda passou a corromper os padrões morais e por motivos óbvios: "Quanto maior a parte das pernas à mostra, mais fácil é imaginar o ponto onde elas se encontram” (MORRIS, 2007, p. 279). Esta é a razão do fetiche e tabu que as rodeia, impulsionando a valorização do erotismo das pernas, tanto que exibi-las já foi considerado um convite sexual. Após a Primeira Guerra Mundial as pernas saíram do esconderijo, causando assombro e furor. As saias mais curtas refletem uma sociedade cheia de energia sexual, e as longas certo moralismo; porém, erguidas ou movidas, podem provocar forte impacto, mesmo quando bloqueiam os sinais sexuais emitidos pelas pernas.

Quanto às roupas masculinas, as das peças são modernas e estas surgem no século XVIII, quando da redescoberta dos valores neoclássicos que acabaram por ditar uma nova estética para o corpo masculino, ornamentado por roupas traçadas em linhas retas e verticais compondo, no geral, um visual simples e sóbrios no corte e nas cores, quase inexpressivas em razão de esconderem os contornos do corpo masculino. As roupas masculinas buscavam e ainda buscam destacar certas partes do corpo como tórax, ombros e braços, passando a ideia de solidez, virilidade, força e poder, tudo o que se espera socialmente de um homem. Este tipo de roupa imprimia a ideia do herói, sem esquecer que o corpo do herói tem um apelo erótico. Porém, mesmo essa sobriedade peculiar, não impediu de apresentar uma sexualidade latente, pois ao buscar o padrão de beleza apolíneo ${ }^{15}$, aproxima os homens de semideuses (SIMÃO, 2011).

Encerrando esta parte, uma palavra breve sobre o abraço na peça em tela. Os braços são como bandeiras corporais, com capacidade de transmitir certos sinais em muitas ações, sendo, em geral, amigáveis e assexuados, por isso são considerados uma parte neutra do corpo (MORRIS, 2007). Porém, o tipo de abraço informa muito, sobre amizade ou intimidade; um um contato corporal pequeno fala de um abraço amigável, e um contato corporal mais estrito fala de intimidade. Assim, a altura dos braços e/ou posição das mãos - se pousam nos quadris do/a parceiro/a -, emitirão mensagens corporais de intimidade e até mesmo eróticas, com clara conotação sexual.

\footnotetext{
${ }^{15}$ A beleza apolínea, remete ao Deus Grego Apolo e simboliza a forma perfeita.
} 
Considerando estes argumentos, consideramos que com esta peça, da perspectiva do gênero e da sexualidade, artesãos e artesãs estão representando o erotismo heteronormativo, na medida em que insinuam a reprodução e a continuidade da vida. Bataille (1987) argumenta que os corpos travam uma intensa busca pela superação do isolamento, do fechamento e da solidão, única via que garantirá a continuidade da vida. Em Bakhtin (1987), os corpos se encontram para abrir-se ao erotismo que está ligado à reprodução da vida por temor da morte. Ambos os autores falam aqui do erotismo heterossexual.

A exuberância e a continuação da vida parece ser uma mensagem bastante clara nos ateliês, muito recorrente em uma cidade ribeirinha como Abaetetuba, na qual o casamento juvenil ainda é um valor muito cultivado, já que é comum que jovens - rapazes e moças já se encontrem casados e com filhos entre 18 e 22 anos, talvez para domar os ímpetos do desejo supostamente desgovernados da juventude, ou quem sabe para salvaguardar as famílias já formadas. De qualquer modo, artesãos e artesãs respiram a defesa da continuação da vida, em uma atmosfera na qual só há lugar para o erotismo como exuberância da vida.

A descrição e intepretação introdutória desta peça tem apenas a intenção de mostrar sua potencialidade analítica, pois como brinquedo ou artesanato ${ }^{16}$ fica encoberta por uma aura de inocência e beleza. Mas exposta, circulará pela sociedade, lançando um conjunto de significados que reforçará a economia de gênero e seus princípios organizadores para o cuidado com o corpo. Os significados flutuarão livres e desimpedidos. A legenda é do expectador e da expectadora, sujeito olhante, à semelhança de um voyeur para Foucault (1998).

\section{O corpo e a representação da heteronormatividade}

Estamos considerando a representação como "[...] como inscrição, marca, traço, significante e não como processo mental" (SILVA, 1999, p. 32), o que a faz ser concreta, visível e tangível. Assim considerada, a representação adquire sentido quando colada a certa cadeia de significados, neste caso os de gênero e de sexualidade.

Uma mirada rápida pode não perceber as ambivalências entre significados e significantes devido ambos se encontrarem disseminados pela peça e ser adequados ao referente. Essa adequação restringe a pergunta: o que é isso? pois de antemão já é possível saber que se trata de um casal, formado por um homem e uma mulher. É assim porque essa é a função de um quadro, de um desenho e, neste caso, desta escultura miniaturizada, qual seja, "[..] deixar aparecer sem equívocos nem hesitação aquilo que [...] representa" (FOUCAULT, 1998, p. 20). Até por que o corpo é o responsável imediato por nossa identificação. Os traços e marcas da peça conservam as marcas do referente espalhados por toda sua superfície. A figura em forma de escultura dissemina os princípios organizadores que conformam um corpo quase sem paradoxos, sendo desnecessário explicação adicional para ser compreendida, pois está assegurado seu reconhecimento (FOUCAULT, 1998). No contexto do realismo a imagem é o reflexo do real, porém, como bem argumenta Silva (1999), tem havido contestação e desobediência das identidades culturais subjugadas contra os muitos modos dominantes de representação, em razão de pretenderem representar a totalidade do humano e do mundo. Além da contestação identitária, há outra razão para tal, qual seja a própria natureza desta noção de representação, que a faz ultrapassar as fronteiras do realismo, para trilhar tateante o solo movediço de outra epistemologia - errante e incerta - mas que a delineia como construção discursiva, social e histórica.

\footnotetext{
${ }^{16}$ É comum referir a estes artefatos como brinquedos de miriti, o que os associa à infância e ao lúdico; porém, por ser quebradiços e efêmeros, não duram nas mãos de uma criança.
} 
Da perspectiva desta noção de representação, a peça casal de namorados-casal de dançarinos mesmo que não represente o "verdadeiro" casal de namorados-casal de dançarinos, precisa ser considerada como um modo de produção da verdade sobre o corpo masculino e feminino. Deste ponto de vista, é, em certa medida, uma prisão volátil em razão das lutas culturais permanentes em torno dos significados.

Assim, a despeito da segurança do reconhecimento, este não é um casal de namorados-casal de dançarinos. Trata-se de uma peça artesanal, cujas marcas e traços (contornos do corpo, roupas, cabelos) são apenas a representação cultural do significante. A peça apenas mostra a forma corporal de um homem e de uma mulher, mas não "falam" tudo, pois a representação visual nunca é dada de uma única vez, já que "Barcos, casas, gente, são ao mesmo tempo formas reconhecíveis e elementos de escrita" (FOUCAULT, 1998, p. 40). É a qualidade de escrita que imprime um caráter provisório e arbitrário às figuras representadas. Logo, os signos não estão encerrados e subordinados à forma, sendo provável supor outras leituras e formas no exterior das peças.

Os signos dos quais fala Foucault (1998) não estão encerrados no corpo, visto que este é provisório, é produto da cultura conforme Goelnner (2003), contingente em razão dos tempoespaços diferentes, e passível de intervenções socioculturais variadas. O corpo recebe intervenções mas também reage obedecendo e desobedecendo. Por isso a identificação inequívoca entre o corpo e a imagem do homem e a da mulher é uma ficção, pois entre significados, marcas e o referente há espaços difíceis de decifrar, há superfícies sempre reversíveis (FOUCAULT, 1987). Ao final, esteesta pode não ser um homem ou uma mulher tal como definidos pela roupa que veste ou pelo corte de cabelo, mas tão somente a imagem de um homem ou de uma mulher culturalmente ideal. A constituição do feminino e do masculino, bem como da sexualidade é fluída, em razão de ser atravessada por condições históricas e culturais, o que impede a fixidez e os binarismos (SCOTT, 1995), e provoca rachaduras quase invisíveis na sua superfície.

Um argumento adicional em favor das fissuras e da reversibilidade. Hoje, nos ateliês, talvez uma peça representando um casal homoafetivo seja considerada abjeta, devido à força da cultura de gênero que valoriza a divisão de tarefas e a continuidade da vida. Porém, com Butler (1999), o controle do sujeito da ação não é absoluto, e segundo Louro (2004) a imposição da matriz heterossexual também deixa fissuras à contestação. Diante deste controle parcial do sujeito e da sociedade, adicionamos a posição de Ríos (2007), pois parece o ingrediente que falta. $\mathrm{O}$ autor argumenta que é preciso experimentar outra arte de viver, ancorada na éticaestética da diferença, o que fará circular outros princípios organizadores para o cuidado com o corpo. Quando este momento chegar estes princípios organizadores poderão ser renegociados.

Encerramos argumentando que o terreno fica aberto para outras miradas, daqueles e daquelas que nas experiências cotidianas se aventuram a inventar criativamente outros corpos, outras representações, outros masculinos e outros femininos, serpenteando por entre infindáveis manobras espaciais e imagéticas. Esta ação só é possível porque o processo de significação é sempre indeterminado.

\section{Considerações provisórias}

Os artefatos em miriti constituem uma tradição bicentenária e são certificados como patrimônio cultural imaterial do Estado do Pará. Esta tradição chegou aos dias atuais mantida pela iniciativa de associações e pelo trabalho de artesãos e artesãs, que os produz em um processo que denominamos de produção generificada, há muito naturalizada. Um dos efeitos deste processo de naturalização é a modelagem e montagem da peça casal de namorados-casal de dançarinos. Nesta peça, a plástica dos corpos masculino e feminino é desenhada em atenção aos princípios organizadores contidos na cultura de gênero. Além de reafirmar as normas de gênero e sexualidade 
que transitam na sociedade mais ampla, ao compor um casal heteronormativo, a peça também insinua o erotismo enquanto exuberância da vida, proporcionado pelo encontro de corpos para a reprodução. Acreditamos, seguindo Foucault (1987) que a identificação inequívoca do corpo é uma ficção, pois em sua superfície há espaços reversíveis; acreditamos também na possibilidade de contestação das normas de gênero sedimentadas nos ateliês e mais, em outra arte de viver, orientada pela ética-estética da diferença.

Resta dizer que a pesquisa continua e seguimos produzindo informações que podem servir para mudar o que sabemos, indicando outras interpretações e novas problematizações.

\section{Referências}

BAKHTIN, Mikhail. Cultura Popular na Idade Média: o contexto de François Rabelais. Trad. Yara F. Vieira. São Paulo: Hucitec/UNB, 1987.

BATAILLE, Georges. O erotismo. Trad. Antonio Carlos Viana. Porto Alegre: L\&PM, 1987.

BHABHA, Homi K. O local da cultura. Belo Horizonte: Editora UFMG, 1998.

BORDO, Susan R. O corpo e a reprodução da feminidade: uma apropriação feminista de Foucault. In: JAGGAR, Alisson M.; BORDO, Susan R. Corpo, gênero e conhecimento. Trad. Brítta Lemos de Freitas. Rio de Janeiro: Record/Rosa dos Tempos, 1997.

BUTLER, Judith. Problemas de gênero: feminismo e subversão da identidade. Trad. Renato Aguiar. Rio de Janeiro: Civilização Brasileira, 2003.

CANCLINI, Néstor G. Culturas Híbridas. São Paulo: Edusp, 1989.

CERTEAU, Michel de; GIARD, Luce; MAYOL, Pierre. A Invenção do cotidiano: as artes do fazer. $15^{\mathrm{a}}$ Ed. Petrópolis: Vozes, 2008.

CLIFFORD, James. A Experiência etnográfica: antropologia e literatura no século XX. Rio de Janeiro: Editora UFRJ, 1998.

FOUCAULT, Michel. Vigiar e punir. 27ª Edição. Petrópolis: Vozes, 1987.

. Isso não é um cachimbo. $3^{\text {a }}$ Ed. Rio de Janeiro: Paz e Terra, 1998.

GOELLNER, Silvana V. A produção cultural do corpo. In: LOURO, Guacira L.; NECKEL, Jane F.; GOELLNER, Silvana V. (Orgs.). Corpo, gênero e sexualidade: um debate contemporâneo na educação. Petrópolis: Vozes, 2003.

HOBSBAWN, Eric; RANGER, Terence. A invenção das tradições. Rio de Janeiro: Paz e Terra, 1984.

JOHNSON, Richard. (Org.). Estudos Culturais: uma introdução. In: SILVA, T. T. (Org.). $O$ que é, afinal, Estudos Culturais. Belo Horizonte: Autêntica, 2000.

LOURO, Guacira L. Um corpo estranho: ensaios sobre sexualidade e teoria queer. Belo Horizonte: Autêntica, 2004. 
MORRIS, Desmond. A mulher nua: um estudo sobre o corpo feminino. São Paulo: Editora Globo, 2007.

RIBEIRO, Joyce; SARGES, Lidia; PINHEIRO, Delisa. A cultura de gênero nos ateliês de produção do brinquedo de miriti. In: RIBEIRO, Joyce e outros. A pesquisa no Baixo Tocantins: resultados de pesquisa. São Paulo: Livraria da Física, 2015.

RÍOS, Rubén H. Michel Foucault y la condición gay. Madrid: Campo de Ideas SL, 2007.

SCOTT, Joan. Gênero: uma categoria útil de análise histórica. Educação \& Realidade, Porto Alegre: FACED/UFRGS, v. 20, n. 2, jul/dez, 1995.

SILVA, Tomas T. O currículo como fetiche: a poética e a política do texto curricular. Belo Horizonte: Autêntica, 1999.

Teoria cultura e educação: um vocabulário crítico. Belo Horizonte: Autêntica, 2000.

SILVEIRA, Flávio L. Miriti das Águas, das ilhas... de Abaeté. FERNANDES, Paulo; SCHUBER, Vilson; CAL, Carmem L.V. (Org.). Miriti das Águas. Belém: SECULT/SEBRAE, 2012.

SIMÃO, Luiza A. M. A influência do corpo masculino na construção do terno contemporâneo. ECOM, São Paulo, 2011.

STALYBRASS, Peter. O casaco de Marx: roupas, memórias, dor. Belo Horizonte: autêntica, 2000. 